\title{
PENINGKATAN PRODUKTIVITAS LINE STITCHING, PADA INDUSTRI ALAS KAKI DENGAN METODE OEE (OVERALL EQUIPMENT EFFECTIVENESS) STUDI KASUS DI PT PRATAMA ABADI INDUSTRI
}

\author{
Ismi Mashabai ${ }^{1}$, Revino $^{2}$ \\ Program Studi Teknik Industri Fakultas Teknik Institut Sains dan Teknologi Nasional ${ }^{1}$ \\ Dosen Fakultas Teknik Institut Sains dan Teknologi Nasional ${ }^{2}$ \\ ismimashabai17@gmail.com
}

\begin{abstract}
Productivity is an important point of the existence of the industry. PT Pratama Abadi Industri, which is one of Nike's footwear industry, need to increase their productivity. To achieve these objectives, this thesis using the method of Overall Equipment Effectiveness (OEE) in order to increase productivity, especially in the production process of stitching line. OEE value calculation results in line stitching for 2 years was $49.99 \%$ in the first year (SEP, 2014 s / d Agus 2015) <85.00\% (world standard OEE values) and 50.81\% in the second year (SEP $2015 \mathrm{~s}$ / d Agus 2016) $<85.00 \%$ (world standard OEE values). The three variables that cause low OEE value is the loading time, the total pieces and defect.
\end{abstract}

Key Words: Increase Productivity, Overall Equipment Efectiveness, Fishbone \& PDCA

\section{PENDAHULUAN}

Dalam dunia pekerjaan, seseorang dituntut untuk menghasilkan suatu hasil pekerjaan yang maksimal. Dengan kata lain seseorang dituntut harus produktivitas. Produktivitas adalah poin penting dari eksistensi industri. Produktivitas juga merupakan parameter organisasi dalam mengukur kinerja dari sumber dayanya, baik sumber daya manusia maupun juga unit bisnis dari organisasi. Ada benang merah antara upaya meningkatkan kualitas dan produktivitas. Dengan adanya perbaikan kualitas, maka akan berdampak terhadap 2 hal, yakni peningkatan penjualan dan pengurangan biaya. Berdasarkan informasi Jakarta (Pos Sore) Selasa (24/11/2015) menaker Hanif Dhakiri berkata "Saat ini tingkat produktivitas Indonesia pada tren yang membaik, namun Gerakan Nasional Peningkatan Produktivitas perlu digelorakan kembali sebagai perwujudan Nawacita Produktivitas," dalam laporannya kepada Presiden pada acara penyerahkan penghargaan produktivitas Paramakarya 2015 kepada 22 perusahaan usaha mikro, kecil dan menengah. Dibandingkan dengan negara lain, tingkat Produktivitas tenaga kerja di Indonesia pada 2015 cukup baik ketimbang 2011. Namun masih lebih rendah dari rata-rata negara anggota APO. Singapura, misalnya, memiliki tingkat produktivitas tertinggi di dunia pada tahun 2015, yaitu sekitar US\$121,9 sementara Indonesia hanya sekitar US\$21,9. Posisi Indonesia pada tahun 2015, juga masih berada dibawah Malaysia dan Thailand bahkan Sri Lanka, dan diatas Filipina dan Vietnam. Hal ini dibutuhkan untuk meningkatkan pertumbuhan ekonomi yang pada ujungnya bisa mencapai kesejahteraan bagi masyarakat. Sepatu dengan merk Nike merupakan sepatu terpopuler di dunia. PT Pratama Abadi Industri merupakan salah satu perusahaan pembuatan sepatu Nike. Dengan memproduksi sepatu Nike dalam berbagai macam ukuran dan jenis. Dari sepatu ukuran baby hingga sepatu ukuran dewasa. Baik sepatu untuk wanita dan juga sepatu untuk pria. Beberapa factroy sepatu nike di Tangerang diantaranya PT Pratama abadi industri, PT Nikomas gemilang, PT Adis dimension footwear, PT Kmk global sports, PT Ching luh Indonesia, PT Panarub dwikarya dan PT Doson Indonesia.

PT Pratama Abadi Industri sendiri merupakan salah satu perusahaan yang berfokus pada pembuatan produksi sepatu dengan satu jenis merk, yakni Nike. Karena proses produksinya yang berkualitas, sepatu Nike telah terekspor lebih dari 80 negara tujuan (Amerika, Eropa, Afrika dan Asia). Sebagai perusahaan yang mementingkan kualitas produk, PT Pratama Abadi Industri dalam proses pemasarannya memberikan tanggung jawab dan wewenang penuh kepada pemegang lisensi yang mempunyai kantor perwakilan di Indonesia. Nike memiliki berbagai macam jenis sepatu olah raga, antara lain sepatu bola, sepatu tenis, sepatu basket dan sepatu lari. Dari berbagai jenis sepatu tersebut, PT Pratama Abadi Industri bergerak dalam bidang manufactur sepatu lari (Running shoes). PT Pratama Abadi Industri merupakan suatu perusahaan Penanaman Modal Asing (PMA) dari Korea yang berbentuk Perusahaan Terbatas (PT), sekaligus sebagai kawasan berikat. Perusahaan ini merupakan sebuah industri padat karya yang bergerak di bidang industri sepatu olahraga khususnya sepatu Nike dengan semua SOP (Standar Operasional Prosedur) sesuai 
mengacu pada COC (Code of Conduct) Nike. Karena itu, perusahaan harus selalu mengutamakan kualitas dan mutu produk dengan adanya pengujian dan pertahanan atas kualitas yang disertai pula keanekaragaman produk sepatu untuk berbagai aktivitas olahraga. Dalam proses produksi, dibutuhkan metode yang efektif dan efisien agar fasilitas-fasilitas yang digunakan dalam proses produksi di industri mendapatkan hasil yang maksimum. Gambaran tentang PT Pratama Abadi Industri dipaparkan dengan tujuan untuk melihat progres capaian yang akan mempengaruhi sistem kerja perusahaan, dalam hal ini adalah produk sepatu Nike yang dihasilkan dengan menggunakan metode pengembangan OEE (Overall Equipment Effectiveness) dengan melihat efektivitas line stitching Model Cortez. Total Productive Maintenance (TPM) merupakan suatu filosofi yang bertujuan untuk memaksimalkan efektivitas dari fasilitas yang digunakan di industri, tidak saja dialamatkan pada perawatan saja tapi semua aspek dari operasi dan instalasi dari fasilitas produksi. Ada enam besar (six big losess) dalam proses produksi yaitu disebabkan oleh kerusakan peralatan dan mesin saat produksi (breakdown), kalibrasi peralatan (set up) yang salah, pemberhentian waktu produksi sesaat, kerusakan pada saat persiapan, cacat produksi, serta penurunan laju produksi TPM diterapkan dengan manganalisa permasalahan yang terjadi pada setiap peralatan dan mesin tertentu dengan suatu metode perhitungan Efektivitas Peralatan Menyeluruh (Overall Equipment Effectiveness) atau OEE dari kualitas produk di tiap peralatan dan mesin produksi. Nilai OEE ini ditentukan oleh Availibility (ketersediaan), Performance (kinerja) dan Total Yield/ Qualitas (produk) (Syarief, 2010). Pemilihan line stitching dalam tesis ini dikarena stitching memiliki hasil yang rendah dibandingkan dengan line cutting, assembling dan stockfit. Berdasarkan data record produksi dari bulan September 2014 sampai dengan Agustus 2016 line produksi cutting, assembling dan stockfit menunjukkan hasil produksi yang stabil dengan pencapaian diatas $90 \%$ dari target produksi. Bahkan di beberapa bulan hasil produksi mencapai $100 \%$ lebih, melebihi target produksi. Sedangkan line stitching hasil produksinya tidak stabil dengan pencapaian rata-rata diangka $75 \%$ sampai dengan $89 \%$ dari target produksi. Bahkan di bulan Juli 2016, hasil produksi line stitching hanya mencapai $52 \%$.

\section{METODE}

Penelitian ini dilakukan di PT Pratama Abadi Industri. Sumber data penelitian ini adalah: 1) Bagian PPIC data onhand order, jumlah produksi yang telah dischedule dan data jumlah produksi secara aktual sesuai line produksi. 2) Bagian Stitching untuk data produksi, hasil output dan down time mesin. 3) Bagian perawatan (maintenance) untuk data kerusakan mesin serta data reguler perawatan mesin. 4)Bagian quality control untuk data jumlah produksi rework. Dari hasil data yang terrecord dari bulan September 2014 sampai dengan Agustus 2016.

Populasi dan sampel penelitian ini adalah Dept.head per factory PT Pratama Abadi Industri. Sampel yang diambil dalam penelitian ini adalah pada bagian Stitching, maintenance, quality control dan PPIC. Yang menjadi alasan dalam memilih sampel ini adalah Dept.head per factory memiliki akses menyeluruh dalam satu gedung produksi. Memudahkan dalam berkomunikasi dengan para Leader dan karyawan proses produksi, pengambilan data hasil produksi, total karyawan, jam kerja karyawan, data defect dan data-data lain yang dibutuhkan dalam penelitian ini. Bagian Stitching berhubungan dengan hasil produksi harian secara aktual. Pada bagian maintenance memiliki informasi untuk data tentang perawatan serta perbaikan mesin produksi. Sedangkan pada bagian quality control memiliki informasi untuk data produk yang defect. Dan untuk bagian PPIC untuk mendapatkan informasi mengenai jumlah produksi yang ditargetkan dan jumlah produksi yang dihasilkan.

Pengumpulan dan pengolahan data penelitian tesis ini adalah pengumpulan data-data yang didapat kemudian di olah, penulis dapatkan dari bagian Stitching, bagian maintenance, bagian quality control dan juga bagian PPIC. Dari data yang diperoleh, diolah untuk mendapatkan nilainilai sbb: 1) Machine working time, 2) Planned down time, 3) Loading time / Planned Production Time, 4) Operating Time, 5) Availability, 6) Performance, 7)Quality dan 8) OEE.

Teknik pengumpulan data dengan menggunakan metode pengolahan data history selama 2 tahun yang telah didokumentasi oleh perusahaan. Data penelitian ini diperoleh melalui wawancara dan data skunder dari bagian Stitching, maintenance, quality control dan PPIC. Data yang sudah didapat kemudian dikumpulkan dengan menggunakan metode non participant observation yaitu dengan mencatat (mengcopy) data yang terdokumentasikan di PT Pratama Abadi Industri.

Untuk teknik pengolahan data dilakukan dengan menggunakan Tools OEE dan Software Microsoft Excel 2007 serta Software SPSS. Pengujian sampel dilakukan untuk mengetahui perbedaan variabel - variabel OEE yaitu availability, performance dan quality rate. Dan analisis deskriptip yang ditujukan untuk memberikan gambaran umum dari data yang diperoleh. Perhitungan OEE dilakukan dengan tahapan perumusan sebagai berikut :

\section{Availability (Ketersediaan)}

$$
\frac{\text { Operating time - Breakdown time - Set up and adjusment time }}{\text { Operating time }} \times 100 \%
$$


2. Performance (Kinerja)

$\frac{\text { Total pieces } X \text { Cycle time }}{\text { Operation time }} \times 100$

3. Quality Rate

$\frac{\text { Produksi total }-(\text { Jumlah cacat }+ \text { rework produk })}{\text { Produksitotal }} \times 100 \%$

4. Overall Equipment Effectiveness

Availability Rate x Performance Rate x Quality Rate

\section{HASIL DAN PEMBAHASAN}

Overall

Equipment

Effectiveness merupakan pengukuran efektivitas peralatan secara keseluruhan untuk mengevaluasi seberapa pencapaian performansi. OEE merupakan indikator performansi produktivitas yang didasarkan pada level tertentu dari performansi yang diharapkan. Nilai Overall Equipment Effectiveness (OEE) dipengaruhi oleh tiga faktor yaitu Availability, Performance dan Quality. Menurut standar dunia, ideal dari niali OEE adalah Availability sebesar 90,0\%, Performance sebesar 95,0\%, Quality sebesar 99,9\% dan Overall Equipment Effectiveness (OEE) sebesar $85.0 \%$.

Setelah dilakukan perhitungan OEE di line stitching dari bulan September 2014 sampai dengan Agustus 2016. Hasil dari hitungan tersebut adalah pencapaian nilai OEE line stitching lebih rendah dari nilai standar OOE, yaitu $85 \%$.

Dari perhitungan nilai efektivitas terdapat 1 varibel yang telah mencapai taget, yaitu availability periode Sep 2014 s/d Agus 2015 sebesar $90,01 \%$. Sedangkan variabel performance dan quality pada periode tersebut tidak memenuhi target. Untuk periode Sep 2015 s/d Agus 2016 ketiga variabel availability, performance dan quality tidak memenuhi target, sehingga menyebabkan rendahnya nilai OEE (Overall Equaipment Effectiveness). Nilai OEE line stitching rata-rata 50,04\% dengan perbandingan nilai OEE pada periode Sep 2014 s/d Agus 2015 sebesar 49,99\% dan OEE pada periode Sep 2015 s/d Agus 2016 sebesar $50,81 \%$.

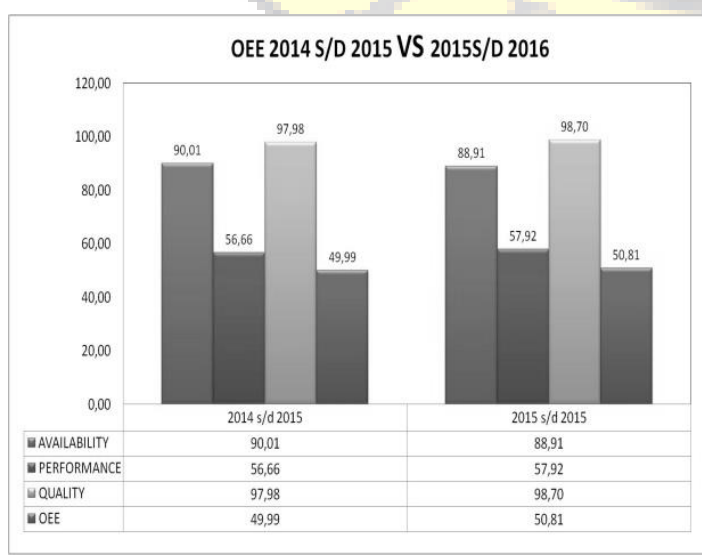

Sumber: PT Pratama Abadi Industri
Dari diagram diatas dapat dilihat bahwa nilai OEE line stithing pada periode Sep Sep 2014 s/d Agus 2015 lebih rendah dibandingkan dengan nilai OEE pada periode 2015 s/d Agus 2016, dengan nilai perbedaan sebesar 0,82 . Ada 2 variabel yang memiliki nilai tinggi pada periode Sep 2015 s/d Agus 2016 yaitu nilai performance dan nilai quality.

Variabel Yang Menyebabkan Nilai OEE Rendah

\section{Nilai Availability}

Dalam menghitung nilai avalibility terdapat tiga variabel waktu pengukuran yaitu operating time, loading time, dan lost time. Dalam perhitungan nilai avalibility line stitching di PT Pratama Abadi Industri ini, variabel waktu yang dihitung adalah operating time dan loading time. Karena 2 variabel waktu tersebut yang terdokumentasikan oleh perusahaan. Dari ke 3 variabel nilai-nilai tersebut, dapat dipastikan jika nilai operating time tinggi maka akan menghasilkan peningkatan pada nilai Overall Equipment Effectiveness (OEE). Dan jika nilai loading time dan lost time tinggi akan mengakibatkan penurunan nilai Overall Equipment Effectiveness (OEE). Berdasarkan dari hasil perhitungan yang telah dilakukan, nilai Availability line stitching periode September 2014 s/d Agustus 2015 adalah 90,01\%. Dan untuk periode September 2015 s/d Agustus 2016 adalah 88,91\%. Standar untuk nilai Availability yang ideal adalah $90 \%$, hasil yang didapat dari nilai Availability line stitching periode September 2014 s/d Agustus 2015 sudah mencapai nilai yang telah distandarkan. Sedangkan di periode September 2015 s/d Agustus 2016 nilai Availability line stitching masih dibawah nilai yang telah distandarkan, masih kurang $1,09 \%$.

\section{Nilai Performance}

Dalam mendapatkan nilai performance terdapat tiga variabel pengukuran yang menentukan nilai, yaitu total pieces, cycle time dan operating time. Dari nilai koefisien tiap-tiap variabel tersebut terlihat bahwa setiap peningkatan total pieces akan menyebabkan peningkatan nilai OEE sebaliknya peningkatan pada operating time dan ideal run rate baik salah satu maupun keduanya akan menyebabkan penurunan pada nilai OEE. Berdasarkan perhitungan, performance line stitching untuk 2 tahun telah mencapai $85,62 \%$. Dengan perbandingan performance pada periode Sep 14 s/d Agus 15 adalah 56,66\% dan periode Sep 15 s/d Agus 16 adalah 57,92\%. Nilai Performance ideal menurut standar dunia adalah $95 \%$, dari persentase yang telah diraih ini berarti performance line stiching dapat dikatakan rendah. Nilai performance pada periode Sep 14 s/d Agus 15 
masih kurang dari standar dengan kekurangan sebesar 38,34\% dan pada periode Sep 15 s/d Agus 16 kurang dari standar dengan kekurangan sebesar $37,08 \%$.

\section{Nilai Quality}

Untuk mendapatkan niali quality terdapat dua variabel pengukuran yaitu total produksi dan total defect produksi (cacat+rework). Dengan adanya peningkatan total defect maka akan menyebabkan penurunan nilai quality. Berdasarkan perhitungan yang telah dilakukan, maka didapat nilai quality line stitching untuk periode 2 tahun adalah 147,33\%. Dengan perbandingan quality pada periode Sep 14 s/d Agus 15 adalah 97,98\% dan periode Sep 15 s/d Agus 16 adalah 98,70\%. Nilai Quality yang ideal sesuai dengan standar dunia adalah 99,9\%. Dari persentase yang telah diraih ini berarti quality line stiching dapat dikatakan rendah. Nilai quality pada periode Sep 14 s/d Agus 15 masih kurang dari standar dengan kekurangan sebesar $1,92 \%$ dan pada periode Sep 15 s/d Agus 16 kurang dari standar dengan kekurangan sebesar $1,21 \%$. Hal seperti ini mengindikasikan adanya persoalan dalam pengendalian kualitas, total defect line stitching untuk periode 2 tahun adalah 69.200 pieces. Dengan perbandingan defect pada periode Sep 14 s/d Agus 15 adalah 39.750 pieces atau 1,68\% dari total produksi sebanyak 2.359.109 pieces dan periode Sep 15 s/d Agus 16 adalah 29.450 pieces atau $1,27 \%$ dari total produksi sebanyak 2.326.158 pieces. Dari data defect yang didapat, peneliti membuat top 5 defect. Dengan membuat Top 5 defect line stitching dapat dilihat yang menjadi defect dominan, sehingga perbaikan dapat dilakukan dengan segera. Top 5 defect line stitching dapat dilihat pada tabel dan grafik sebagai berikut:

Tabel 1. Tabel dan Grafik top 5 defect line stitching

\begin{tabular}{|c|l|c|}
\hline \multicolumn{3}{|c|}{ TOP 5 DEFECT LINE STITCHING } \\
\hline NO & \multicolumn{1}{|c|}{ DEFECT } & QTY \\
\hline 1 & OVER CEMENT & 150 \\
\hline 2 & XTRAY & 184 \\
\hline 3 & LINE UP & 167 \\
\hline 4 & $\begin{array}{l}\text { JAHITAN MARGIN TIDAK KONSISTEN } \\
\text { (EYESTAY / U-THROAT/SWOOSH) }\end{array}$ & 250 \\
\hline 5 & $\begin{array}{l}\text { JARAK SWOOSH KE UPPER TIDAK } \\
\text { KONSISTEN }\end{array}$ & 239 \\
\hline
\end{tabular}

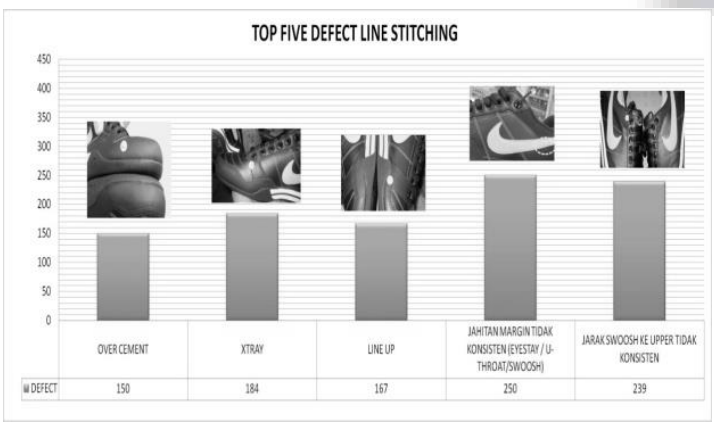

Dari hasil Top 5 defect tersebut maka dihasilkan defect yang paling tertinggi sebanyak 250 pieces, yaitu jahitan margin tidak konsisten (eyestay/uthroat/swoosh).

Dari hasil perhitungan nilai OEE maka, didapat 3 variabel yang menyebabkan nilai OEE rendah. 3 variabel tersebut adalah total pieces, defect, dan jam kerja. Peneliti melakukan dialog dengan manager produksi tentang hal ini. Hasil dari dialog tersebut dapat dilihat dari tabel berikut ini:

Tabel 2. Tabel dan Grafik variabel penyebab nilai OEE rendah

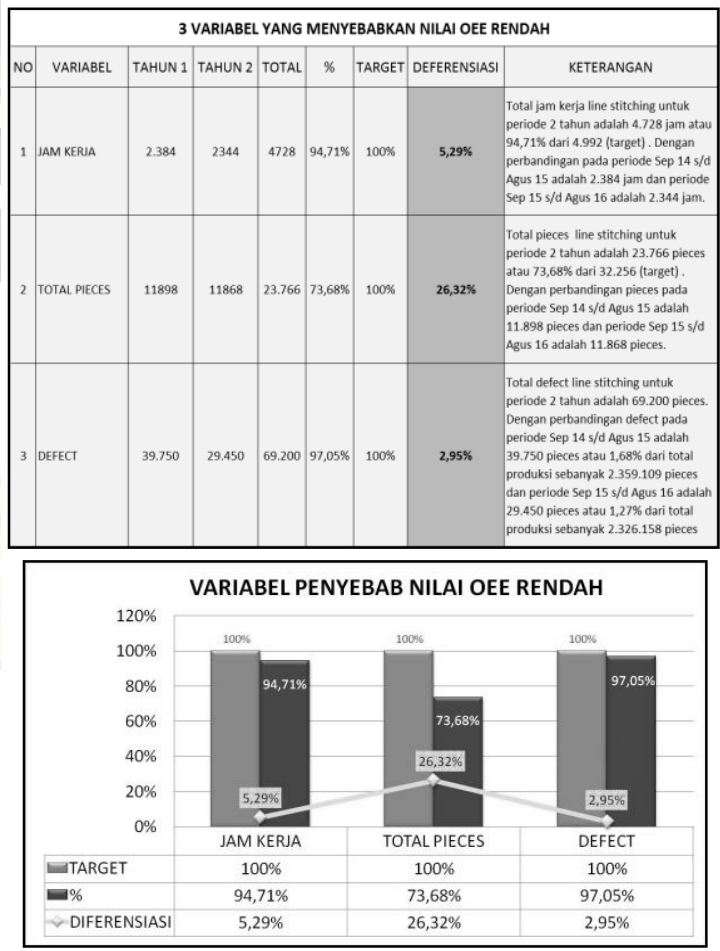

Dari tabel dan grafik di atas dapat disimpulkan bahwa hasil 3 variabel tersebut tidak memenuhi target perusahaan. Sehingga didapat diferensiasi dari masing-masing variabel sebagai berikut: 1) total pieces sebesar 26,32 \%, 2) defect sebesar $2,95 \%$ dan 3) jam kerja sebesar 5,29\%.

\section{PENUTUP}

\section{Kesimpulan}

Berdasarkan hasil penelitian yang telah dilakukan dalam analisis OEE (Overall Equipment Effectiveness) pada line stitching di PT. Pratama Abadi Industri maka penelitian ini dapat disimpulkan sebagai berikut:

1. Dalam sebulan produk yang dihasilkan sebanyak \pm 56.150 pasang sepatu. Sehingga produk yang dihasilkan dalam satu tahun adalah \pm 673.920 pasang sepatu dari total line produksi sebanyak 88 line. 
2. Standar dunia nilai OEE (Overall Equipment Effectiveness) adalah $85,00 \%$. Hasil dari perhitungan peneliti nilai OEE line stitching selama 2 tahun adalah 49,99\% pada tahun pertama (Sep 2014 s/d Agus 2015) <85,00\% (standar dunia nilai OEE) dan 50,81\% pada tahun ke 2 (Sep 2015 s/d Agus 2016) <85,00\% (standar dunia nilai OEE).

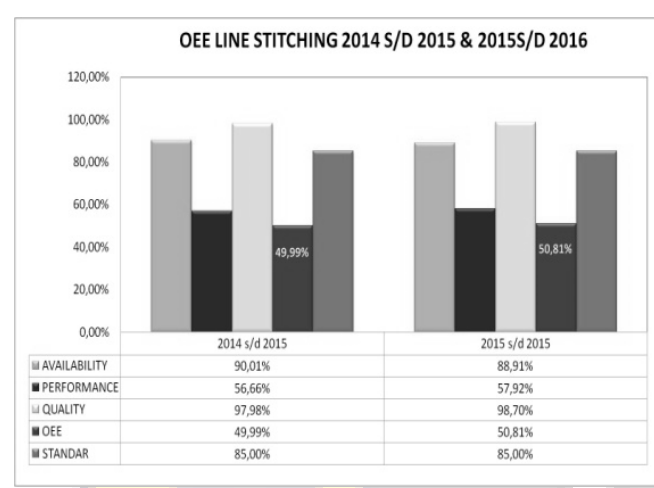

Gambar 6.1 Diagram OEE line stitching Sep 2014 s/d Agus 2015 \& Sep 2015 s/d Agus 2016

3. Dengan mengumpulkan data-data history produksi, meneliti secara langsung di lantai produksi dan hasil dari perhitungan nilai OEE serta dengan menggunakan diagram fishbone. Maka didapat 3 variabel yang menyebabkan nilai OEE rendah, yaitu total pieces hanya mencapai $73,68 \%$ dari target $100 \%$, defect $97,05 \%$ dengan target $100 \%$ yang seharusnya defect tidak ada, dan jam kerja mencapai $94,71 \%$ dari target $100 \%$.

4. Permasalahan yang terjadi pada proses produksi diselesaikan dengan segala usaha dan dukungan dari semua bagian produksi. Baik dari tingkat management hingga operator. Dengan kerja sama yang terorganisir dengan baik, permasalahan yang ada akan dapat segera diselesaikan. Dari hasil pembuatan PDCA, implementasi yang dilakukan pada permasalahan loading time rendah adalah staff produksi bekerjasama dengan team HRD dalam pengaturan cuti karyawan dan tindak lanjutnya adalah leader produksi lebih konsisten dalam pengaturan pengambilan cuti karyawan. Kemudian, implementasi yang dilakukan pada permasalahan total pieces rendah adalah komunikasi antara team gudang bahan baku dengan team material handler (penyediaan komponen pada proses produksi) ditingkatkan dan tindak lanjutnya adalah leader produksi lebih konsisten dalam cek random data ketersediaan bahan baku. Selanjutnya, implementasi yang dilakukan pada permasalahan deceft adalah leader dan team QC bekerjasama dalam melakukan pemisahan komponen swoosh yang tidak konsisten jahitannya dan kemudian jahitan tersebut diperbaiki. Dan tindak lanjutnya adalah leader produksi lebih konsisten dalam cek random kualitas setiap 2jam sekali.

\section{Saran}

Berdasarkan dari penelitian yang telah dilakukan selama ini, peneliti dapat memberikan saran-saran yang sekiranya dapat bermanfaat, antara lain sebagai berikut:

1. Saran teoritis.

a. Faktor-faktor produksi adalah tanah, gedung, mesin, peralatan, bahan mentah dan sumber daya manusia. Jika faktor-faktor tersebut ditingkatkan maka secara sitematis produktivitas dapat ditingkatkan.

b. OEE dapat dijadikan metode industri dalam usaha meningkatkan produktivitas

c. Dengan mengurai akar permasalahan merupakan tindakan yang dilakukan dalam mencari akar penyebab. Sehingga improvement dalam permasalaahan yang terjadi dapat dilakukan dengan cepat dan tersistem.

2. Saran praktis.

a. Perencanaan jam kerja yang terencana akan memaksimalkan jam kerja.

b. Jam kerja line produksi diatur oleh team PPIC yang telah disesuaikan dengan kebutuhan produksi

c. Pengontrolan untuk ketersediaan bahan baku perlu di tingkatkan.

d. Dokumentasi gudang penyimpanan bahan baku diganti dengan sistem ERP. Agar line stitching dapat mengetahui input, ketersediaan dan output bahan baku.

e. Dengan meningkatkan kerja sama antar department dan support yang tinggi dari team management akan dapat meningkatkan kinerja serat mengurangi kegagalan produk/defect/rework.

f. Dengan adanya reward dan punishment bagi line produksi yang mencapai target dan tidak mencapai target di harapkan dapat meningkatkan hasil produksi.

\section{DAFTAR PUSTAKA}

Chaidir, Alex Julius. 2010. “Analisa Peluang Peningakatan Kapasitas Fasilitas Produksi Kantong - Semen Rekat PT XYZ Melalui Evaluasi Kinerja Pemeliharaan Menggunakan Overall Equipment Effectiveness (OEE) dan Overall Line Effectiveness (OLE)". Tesis. Jakarta: Program 
Magister Teknik Industri Universitas Indonesia

Handayani, Endang Mekarsari. 2012. “Analisis Overall Equipment Effectiveness (OEE) Kendaraan Niaga Model SL(l-300) Studi Kasus pada PT. Krama Yudha Ratu Motor Jakarta Timur". Tesis. Jakarta: Program Magister Teknik Industri Institut Sains dan Teknologi Nasional.

Hasanah, Jauharin. 2011. "Perancangan Startegi Kompetensi SDM Untuk Peningkatan Kinerja Tpm Dengan Pendekatan Metode SIX-SIGMA”. Tesis. Jakarta: Program Magister Teknik Industri Universitas Indonesia.

Hasanah, Jauharin. 2011. "Perancangan Strategi Kompetensi SDM Untuk Peningkatan Kinerja TPM Dengan Pendekatan Metode Six Sigma”. Tesis. Depok: Program Magister Universitas Indonesia

Sukwadi, Roland. 2008. "Analisis Perbedaan Antara Faktor-Faktor Kinerja Perusahaan sebelum dan sesudah Menerapkan Strategi Total Productive Maintenance (TPM) (Studi Kasus pada PT. Hartono Istana Teknologi Divisi Produk Home Appliances)". Tesis. Semarang: Program Magister Manajemen Universitas Diponegoro

Sundari, Ernawati Yohana. 2009. "Strategi Penerapan Total Productive Maintenance Sebagaoi Upaya Meningkatkan Efektivitas Mesin Cetak Pada PT Masscom Graphy Semarang”. Tesis. Semarang: Program Magister Manajemen Universitas Diponegoro

Sudradjat, IR. Ating. 2011. Pedoman Praktis Manajemen Perawatan Mesin Industri. Bandung: Refika Aditama.

Syarief, Syafrizal. 2010. "Pengukuran Overall Equipment Effectiveness (OEE) Dengan Labview 8.5 sebagai Pengendali Maintenance”. Tesis. Depok: Program Magister Universitas Indonesia.

Yamit, Zulian. 2013. Manajemen Kualitas Produk dan Jasa. Yogyakarta: Ekonisia.

Zylstra, Kirk. 2005. Lean Distribution. Jakarta: PPM 